\title{
Using oocyte essential fatty acid composition to assess spawner reproductive potential under hypersaline conditions
}

\author{
Julian Döring*, Werner Ekau \\ Leibniz Centre for Tropical Marine Research (ZMT), Fahrenheitstraße 6, 28359 Bremen, Germany
}

\begin{abstract}
Inversion of estuaries in the dry tropics (i.e. salinity increases upstream) against the backdrop of a globally changing climate is forcing migratory clupeid fish species to adapt quickly to modifications in their spawning habitats to ensure reproductive success. Hatching success and survival probabilities of marine fish eggs and early life stages are prone to impairment under high temperature and elevated salinity conditions. Essential fatty acids affect osmoregulation in marine fish early life stages, and deficiencies can therefore be expected to cause elevated offspring mortality under hyperosmotic conditions, ultimately modifying a stock's reproductive potential. Here we show that oocytes spawned by bonga shad Ethmalosa fimbriata inside a hypersaline estuary exhibited significantly higher 20:4 (n-6) proportions (1.6 $\pm 0.7 \%$ of total fatty acids) than oocytes spawned under marine conditions $(0.6 \pm 0.2 \%)$. Further, oocyte proportions in 20:4 (n-6), 20:5 (n-3), and 22:6 (n-3) were positively correlated with water temperature, water salinity, and female reproductive investment (relative batch fecundity, gonado-somatic index, oocyte dry weight). Oocytes spawned during high temperature/high salinity conditions inside the estuary are therefore likely to develop normally under the prevailing conditions. Reproductive potential was determined to be highest in females spawning inside the estuary at the end of the wet season, when temperatures are high and salinities are less stressful due to freshwater input. Results lead to the conclusion that migratory clupeid fishes can maintain their reproductive potential in hypersaline estuaries and lagoons, which potentially allows for sustainable stock sizes.
\end{abstract}

KEY WORDS: Arachidonic acid · Clupeidae $\cdot$ Fatty acids $\cdot$ Maternal effects $\cdot$ Salinity $\cdot$ Temperature $\cdot$ Inverse estuary $\cdot$ Reproductive investment

\section{INTRODUCTION}

The bonga shad Ethmalosa fimbriata (Bowdich, 1825) is a clupeid fish species inhabiting West African coastal and estuarine waters from Mauritania to Angola. It is one of the most important fishes targeted by artisanal fisheries in Cameroon, Ivory Coast, Nigeria, and Senegal (Charles-Dominique \& Albaret 2003). Spawning of E. fimbriata in Senegalese coastal waters mainly takes place during the upwelling season from February to May (CharlesDominique 1982). In the Sine Saloum estuary, this batch-spawning species exhibits a protracted repro-

*Corresponding author: julian.doering@me.com

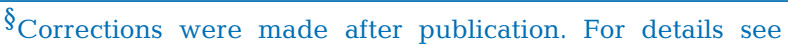
www.int-res.com/abstracts/meps/v584/c_p199-212/

This corrected version: May 23, 2018 ductive period that usually lasts from January to August (Albaret \& Gerlotto 1976, Panfili et al. 2004). Its physiology, which is adapted to eurysaline conditions allows the species to cope with varying salinities from around 0 to 97 (Panfili et al. 2006) and even to reproduce in waters with salinities up to 66 (Charles-Dominique \& Albaret 2003). E. fimbriata is considered a passive filter feeder and undergoes an ontogenetic diet shift, with copepods representing the main prey item for larvae and phytoplankton for adults (Facade \& Olaniyan 1972, Blay \& Eyeson 1982a, Lazzaro 1987). Past studies indicate that the species additionally feeds on benthic deposits such

(C) The authors 2017. Open Access under Creative Commons by Attribution Licence. Use, distribution and reproduction are unrestricted. Authors and original publication must be credited.

Publisher: Inter-Research · www.int-res.com 
as organic detritus and diatoms (Bainbridge 1963, Facade \& Olaniyan 1972).

The Sine Saloum estuary is an inverse hypersaline environment with seasonally changing salinities (Pagès \& Citeau 1990). In the estuary's middle reaches, water temperatures regularly exceed $30^{\circ} \mathrm{C}$ and salinity surpasses 50 by the end of the dry season in June/July (Simier et al. 2004). E. fimbriata exhibits significantly higher batch fecundity when spawning in these hypersaline conditions compared to marine water or freshwater (Scheffers et al. 1972, Albaret \& Gerlotto 1976, Panfili et al. 2006, Döring et al. 2017).

The eggs of E. fimbriata are pelagic and after fertilization spend 3 to $9 \mathrm{~h}$ in the water column until hatching (Albaret \& Gerlotto 1976). Incubation times, however, may vary significantly with water temperature (Jatteau et al. 2017) and salinity (Holliday 1969). Hatching success and survival probabilities of marine fish eggs and early life stages are generally prone to impairment under high temperature and elevated salinity conditions (Hempel 1979, Martin 1988). Thus, maternal effects become increasingly important to ensure offspring survival under extreme environmental conditions. In this regard, the nutritional quality of oocytes, especially in terms of their fatty acid (FA) composition, becomes an important factor in the ontogeny and embryonic development of clupeid fishes in stressful environments (Tocher \& Sargent 1984, March 1993, Tocher 2010). Because of a globally changing climate and the possible inversion of estuaries in the dry tropics (Wolanski 1986, Pagès \& Citeau 1990, Ridd \& Stieglitz 2002, Wedderburn et al. 2016), migratory clupeid fish species have to be able to adapt quickly to rapid changes in their spawning habitats to ensure reproductive success.

FAs are reported to have a strong impact on egg quality, ultimately modifying offspring viability (Castro et al. 2010, Patterson \& Green 2014). FAs such as arachidonic acid (20:4 [n-6]; ARA), eicosapentaenoic acid $(20: 5[\mathrm{n}-3] ; \mathrm{EPA})$, and docosahexaenoic acid (22:6 [n-3]; DHA) cannot be synthesized de novo by marine fishes in significant quantities and for this reason are considered essential fatty acids (EFA) (Sargent et al. 1995). Marine primary producers and some heterotrophic flagellates possess enzymes to desaturate (n-3) and (n-6) polyunsaturated fatty acids (PUFA) through shorter precursors such as oleic acid (18:1 [n-9]) and linoleic acid (18:2 [n-6]) (Dalsgaard et al. 2003). Thus, fishes need to acquire EFA either directly, via consumption of phytoplankton, or indirectly, via consumption of organisms which fed on phytoplankton (e.g. zooplankton) (Ackman \& Jangaard 1964, Lee et al. 1971, Fuiman et al. 2015).
Increasing water temperatures will elevate levels of ARA and saturated fatty acids (SAFA) but lower EPA and DHA contents in marine phytoplankton. This is probably caused by a decrease in enzymatic activity due to lower oxygen availability and the need to maintain cell membrane stability at higher temperatures (Hixson \& Arts 2016). Also, phytoplankton community composition changes under hypersaline conditions, as found in inverse estuaries (Nche-Fambo et al. 2015). Therefore, water temperature and salinity are suspected to have direct effects on the FA composition in food items relevant for E. fimbriata (Bainbridge 1961, Blay \& Eyeson 1982a). In clupeoid fishes, the EFA produced by phytoplankton are incorporated into the intermediate tissues, gonads, and eventually oocytes during the spawning season (Linko et al. 1985, Shirai et al. 2002, Garrido et al. 2007, Castro et al. 2010). Elevated levels of ARA, DHA, EPA, and the DHA/EPA ratio in oocytes accounted for an increased hatching success in a variety of fish species (Leray et al. 1985, Pickova \& Dutta 1997, Lane \& Kohler 2006, Patterson \& Green 2014, Asil et al. 2017). Additionally, EFA play an important role in larval osmoregulation (Bransden et al. 2004). ARA and EPA are substrates for the synthesis of hormone-like compounds called eicosanoids (Bell et al. 1994, Tocher 2003), which are involved in reproduction, hormone release, cardiovascular function, neural function, and osmoregulation in a variety of organisms (Mustafa \& Srivastava 1989). In synergy with hormones, the subfamily prostaglandin modulates the ion and electrolyte balance in the kidney and gills of fishes (Horseman \& Meier 1978, Brown \& Bucknall 1986, Beckman \& Mustafa 1992). Enhanced dietary intake of ARA thus increases prostaglandin production (Bransden et al. 2004) and thereby the resistance to hyperosmotic stress in a variety of fish larvae (Willey et al. 2003, Koven et al. 2003). Also, the ratio of (n-3) to (n-6) PUFA in the gill lipids of European eels Anguilla anguilla (Linnaeus, 1758) reared in seawater was 3fold higher than in individuals reared in freshwater, enhancing their ability to maintain osmotic equilibrium in waters of different salinities at different temperatures (Thomson et al. 1977, March 1993). All these findings imply that a change in the FA composition of phytoplankton communities might severely affect the reproductive potential and ultimately the recruitment success of clupeid fish species reproducing in hypersaline environments.

For the first time, we used EFA to assess the reproductive potential of a clupeid fish, E. fimbriata, under increased salinity conditions. We hypothesized that 
oocyte quality in terms of FA composition is related to the individual's reproductive investment (batch fecundity, gonado-somatic index [GSI], gonad weight, oocyte dry weight [ODW], oocyte volume [OV]) and influenced by ambient temperature and salinity conditions. We chose E. fimbriata from the Sine Saloum in Senegal, as this estuary exhibits a wide range of elevated salinities in which reproduction of the species had been observed.

\section{MATERIALS AND METHODS}

\section{Study sites}

Located $100 \mathrm{~km}$ south of Dakar (between $13^{\circ} 55^{\prime}$ and $14^{\circ} 10^{\prime} \mathrm{N}$ and $16^{\circ} 03^{\prime}$ and $16^{\circ} 50^{\prime} \mathrm{W}$ ), the Sine Saloum estuary is comprised of 3 main branches, the Saloum, the Diomboss, and the Bandiala. An extended dry season, with cool temperatures from November to March and warm temperatures from April to June, is characteristic for this region. July to October is considered the wet and warm season (Simier et al. 2004). Total rainfall has been decreasing since the 1920s, with a particularly severe decline since 1961. Combined effects of tides, reduced river run-off, intense evaporation, and shallow waters in the estuary's mouth have led to high salinity and overall inversion of the salinity gradient (Pagès \& Citeau 1990).

Monthly sampling was conducted at the coast and inside the estuary from February to October 2014, during Ethmalosa fimbriata's main spawning period (Charles-Dominique 1982, Panfili et al. 2004). Three different sites were sampled: Joal (coast, $14^{\circ} 9.1^{\prime} \mathrm{N}$, $16^{\circ} 51.7^{\prime} \mathrm{W}$ ), Djifer (river mouth, $13^{\circ} 57.8^{\prime} \mathrm{N}, 16^{\circ}$ $44.8^{\prime} \mathrm{W}$ ), and Foundiougne (upstream Saloum River, $14^{\circ} 8.1^{\prime} \mathrm{N}, 16^{\circ} 28.1^{\prime} \mathrm{W}$ ) (Fig. 1).

The coastal waters off Joal and in the Saloum River are well mixed and do not show significant stratification (Sloterdijk et al. 2017, Tiedemann \& Brehmer 2017). Thus, only surface water temperatures and salinities were measured for each sampling week. Water temperatures at Foundiougne were recorded with a digital thermometer. For Joal, where catch positions could only be estimated within a radius of $\sim 15 \mathrm{~km}$, and Djifer, average night-time sea surface temperatures were assessed by means of MODIS satellite data (Aqua, level 2, $0.1^{\circ}$ ). At Djifer and Foundiougne, salinity was determined with a handheld refractometer using in situ water samples. For Joal, monthly means in MODIS satellite-derived (Aquarius, level $3,0.5^{\circ}$ ) sea surface salinities were used.

\section{Sampling}

At each sampling site, fish were caught with gill nets (32-36 mm mesh size) by local fishermen and immediately stored on crushed ice after landing. Approximately 1000 fish per sampling site and month were examined to find stage $\mathrm{V}$ females, i.e. mature individuals with ovaries containing fully hydrated oocytes (Blay \& Eyeson 1982b). Females that had spawned recently or lost part of their egg batch during handling were rejected. Spawners were weighed $\left(W_{\mathrm{W}} \pm 0.01 \mathrm{~g}\right)$ and measured $\left(L_{\mathrm{T}}\right.$ nearest $\left.\mathrm{mm}\right)$, and their ovaries were dissected carefully. Oocytes were gently extracted from one ovary lobe, rinsed with deionized water, and counted under a stereomicroscope. Around 70 oocytes per fish were counted, transferred to a pre-weighed tin cap, and deep frozen in liquid nitrogen. Dissected ovaries were transferred to a $4 \%$ borax-buffered formaldehyde and freshwater solution for fecundity analysis and determination of OV. At Foundiougne, spawning females could be sampled in almost all sampling months, allowing a comparison between dry and wet seasons. No hydrated oocytes for FA analysis were obtained at Joal and Foundiougne in February. Across all sampling sites and seasons, 96 females were analysed.

Preliminary data analysis revealed significant spatial differences in oocyte FA composition. It was therefore decided to conduct additional field sampling to obtain basic information on E. fimbriata's feeding habits. This supplementary sampling campaign was conducted in November 2016. Microphytoplankton was collected by casting a handheld net $(20 \mu \mathrm{m}$ mesh size) 3 times per station. Subsequently, phytoplankton

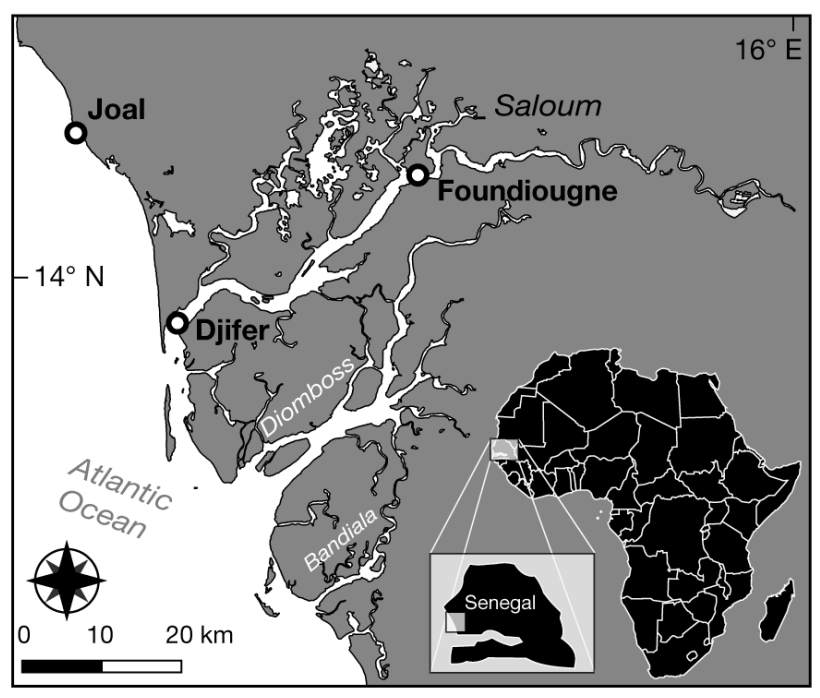

Fig. 1. Senegalese coast and the Sine Saloum estuary, including sampling sites: Joal (coast), Djifer (Saloum River mouth), and Foundiougne (Saloum middle reaches) 
samples were filtered onto micropore filters (Whatman) and transferred to cryovials. The stomach contents of 10 female fishes per sampling site and the counted oocytes of 12 females were transferred into pre-weighed tin caps and also stored in cryovials. All samples were immediately conserved in liquid nitrogen and stored at $-80^{\circ} \mathrm{C}$ in the laboratory.

\section{Assessment of spawner reproductive investment}

Oocytes in tin caps were freeze dried $(24 \mathrm{~h})$ and weighed again to ascertain their dry weights (ODW \pm $0.1 \mu \mathrm{g}$ ). Ten oocytes per ovary fixed in $4 \%$ formalin were photographed under a stereomicroscope and measured along their minor $\left(d_{1}\right)$ and major $\left(d_{2}\right)$ diameters using the calibrated measurement tool in Image J 1.8.0 software (http://rsb.info.nih.gov/ij/). Following Alderdice et al. (1979), the following equation was employed to calculate oocyte volumes $\left(\mathrm{mm}^{3}\right)$ :

$$
\mathrm{OV}=\frac{4}{3} \pi\left(\frac{d_{1}}{2}\right)^{2}\left(\frac{d_{2}}{2}\right)
$$

The gonado-somatic index of female spawners was calculated by dividing the ovary weight (OW \pm $0.0001 \mathrm{~g}$ ) by the ovary-free body weight (OFBW \pm $0.1 \mathrm{~g}$ ) (Zydlewski et al. 2003), as follows:

$$
\text { GSI }=\frac{\text { OW }}{\text { OFBW }} \times 100
$$

Absolute batch fecundity (ABF) was estimated gravimetrically using the hydrated oocyte method for indeterminate spawners (Hunter et al. 1985). Relative batch fecundity (RBF) of the females was calculated by dividing ABF by OFBW (Alheit 1988).

\section{Fatty acid analyses}

Lipid extraction was performed using a 2:1 solvent mix of dichloromethane/methanol. The deuterated FA 12:0 (Larodan, $20 \mathrm{ng}^{-1} \mathrm{l}^{-1}$ ) was added as an internal standard and a deuterated 22:0 FA standard (Lar-

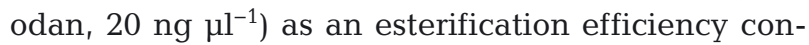
trol. Samples were homogenized using ultrasound. Esterification was performed for $8 \mathrm{~h}$ at $80^{\circ} \mathrm{C}$ in $250 \mu \mathrm{l}$ hexane and $1 \mathrm{ml} 3 \%$ sulphuric acid/methanol solution. All solvents used were gas chromatography (GC) grade. The fatty acid methyl esters (FAME) were analysed in $1 \mu \mathrm{l}$ aliquots injected in an Agilent Technologies 7890B GC system equipped with a polar column (Macherey-Nagel, OPTIMA 225, $30 \mathrm{~m}$ $\times 0.25 \mathrm{~mm} \times 0.25 \mu \mathrm{m}$ ) and a flame ionization detector (base temperature $260^{\circ} \mathrm{C}$ ) with helium as a carrier gas at a constant flow of $1 \mathrm{ml} \mathrm{min}^{-1}$. The column oven was initially set to $40^{\circ} \mathrm{C}$ and then heated at a $100^{\circ} \mathrm{C}$ $\mathrm{min}^{-1}$ increase to $112^{\circ} \mathrm{C}$ for $2 \mathrm{~min}$, at $14^{\circ} \mathrm{C} \mathrm{min}^{-1}$ to $125^{\circ} \mathrm{C}$, at $5^{\circ} \mathrm{C} \mathrm{min}^{-1}$ to $160^{\circ} \mathrm{C}$, at $20^{\circ} \mathrm{C} \mathrm{min}^{-1}$ to $180^{\circ} \mathrm{C}$, at $3^{\circ} \mathrm{C} \mathrm{min}{ }^{-1}$ to $200^{\circ} \mathrm{C}$, at $4^{\circ} \mathrm{C} \mathrm{min}^{-1}$ to $240^{\circ} \mathrm{C}$ for $15 \mathrm{~min}$, and at $20^{\circ} \mathrm{C} \mathrm{m^{-1 }}$ to $260^{\circ} \mathrm{C}$, which was held for $5 \mathrm{~min}$. The system was calibrated with a $20 \mathrm{com}$ ponent marine oil FAME mix (Restek), and chromatograms were analysed using MassHunter Work Station - Quantitative Analysis (Agilent, Version B.07.00) GC software. Three random samples were processed via GC mass spectrometry (Macherey Nagel, OPTIMA FFAplus, $30 \mathrm{~m} \times 0.25 \mathrm{~mm} \times 0.25 \mu \mathrm{m}$, with identical oven parameters as above) to verify FA profiles. To ensure comparability with past studies, results for FA are given as a percentage of the combined weights of all detected FA (Castro et al. 2010).

\section{Statistical analyses}

ANOVA was carried out with FA (as \% of total FA), ODW, OV, and RBF as dependent variables and sampling site, sampling month, and sampling season as independent variables. Given that ANOVA techniques are quite robust against small sample sizes (Brown \& Forsythe 1974) and the violation of the normality assumption (Schmider et al. 2010), data were statistically tested by ANOVA if at least the assumption of homogeneity of variances was met. Data that did not meet the assumption of homogenous variances (Levene's test) were square root transformed. In cases where significant differences were detected, post hoc multiple comparisons were performed (Tukey's HSD).

Multiple linear regression models were applied to assess the responses of RBF and ODW to temperature $\left(T, T^{2}\right)$, salinity $\left(S, S^{2}\right)$, and the interaction between both variables $(T \times S)$. Additionally, the responses of the FAs 18:1 (n-9), ARA, EPA, and DHA to the physical parameters, as well as to either RBF, GSI, or OFBW and OW, were investigated. Non-significant lower-order terms were kept in the model. The resulting minimal adequate models (as determined by corrected Akaike's information criterion) were tested for the constancy of variances (residuals against fitted values) and normal distribution of their residuals (Shapiro-Wilk test). Where any of these 2 assumptions were violated, the response variables were log transformed. This was the case for RBF and for the EFA ARA, EPA, and DHA. To illustrate spatial and seasonal differences in oocyte FA profiles, a principal component analysis (PCA) was performed. 
Relative values for the most abundant FA and EFA were log transformed. All statistical analyses were carried out using JMP 10.0.1 (SAS Institute, www. jmp.com).

\section{RESULTS}

\section{Environmental conditions}

Night-time surface water temperatures at the 3 sampling sites steadily increased throughout the sampling period. Surface temperatures were higher at Foundiougne than at Joal in all sampled months in 2014, with intermediate values recorded at Djifer. However, surface water temperature was highest at Joal $\left(27.8^{\circ} \mathrm{C}\right)$ when compared to Djifer $\left(27.2^{\circ} \mathrm{C}\right)$ and Foundiougne $\left(26.8^{\circ} \mathrm{C}\right)$ in November 2016. At the beginning of the sampling period (February 2014), salinity was determined to be 39 at Foundiougne as well as at Djifer. In the following months, salinity increased steeply at Foundiougne, eventually peaking in July at 54 (end of the dry season) until it dropped to 51 in August (beginning of the wet season) and subsequently to 43 in September and October (end of the wet season). At Djifer, salinity peaked at 43 in July and August before dropping to 32 in September. Coastal salinity at Joal fluctuated around 37 throughout the entire sampling period. Salinity at Joal, Djifer, and Foundiougne in November 2016 was determined to be 37,34 , and 40 , respectively (Fig. 2).

\section{Reproductive investment}

$\mathrm{RBF}$ in female Ethmalosa fimbriata sampled within the Saloum River (Foundiougne, Djifer) was significantly higher than in specimens sampled at the coast (Joal; ANOVA, $F_{(3,68)}$ $=9.4305, \mathrm{p}<0.0001)$. GSI of fecund females was significantly higher at Foundiougne during the wet season when compared to their counterparts sampled at Joal (ANOVA, $F_{(3,70)}=$ 5.4748, p < 0.01; Table 1). ODW at Joal and Djifer did not vary substantially between sampling months. The dry weight of oocytes sampled at Foundiougne, however, peaked in April and decreased significantly during the progression of the sampling period, reaching a minimum in October $\left(\right.$ ANOVA, $F_{(7,40)}=22.5591, \mathrm{p}<$ 0.0001; Fig. 3). Hence, ODW was significantly higher in oocytes sampled at Foundiougne during the dry season when compared to the other sites and seasons (ANOVA, $F_{(3,67)}=7.7573$, $\mathrm{p}<0.001)$. While no monthly differences in OV were detected at Djifer and Foundiougne, OV at Joal was significantly higher in April than in 


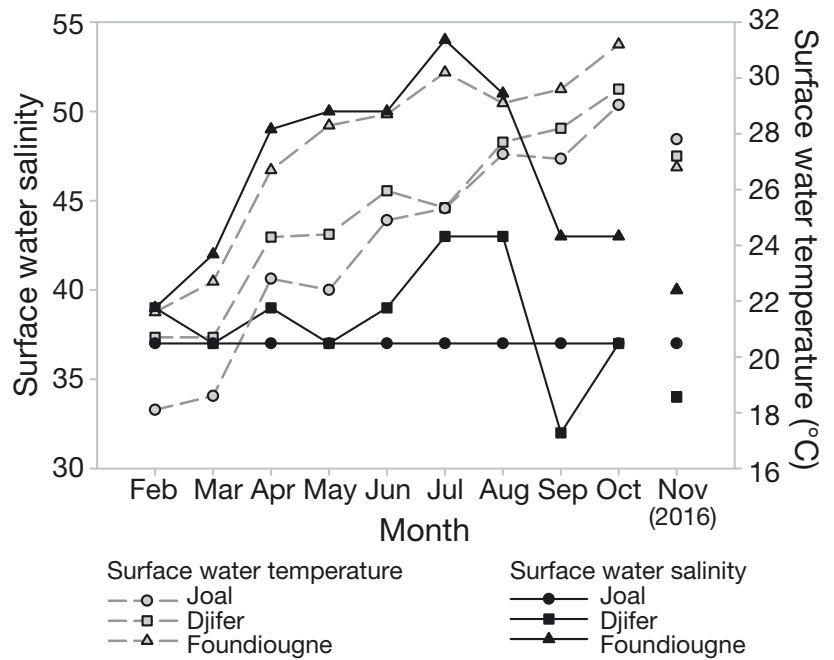

Fig. 2. Surface water temperatures and surface water salinities as recorded at Joal, Djifer, and Foundiougne in 2014 and November 2016

March (ANOVA, $\left.F_{(2,11)}=7.7279, \mathrm{p}<0.05\right)$. However, no significant difference in the total weight of all FA could be detected among sites and seasons (Table 1).

\section{Oocyte fatty acid compositions}

SAFA made up the largest portion of the FA at all 3 sampling sites, followed by monounsaturated fatty acids (MUFA) and PUFA. SAFA and MUFA proportions did not vary substantially among sampling sites

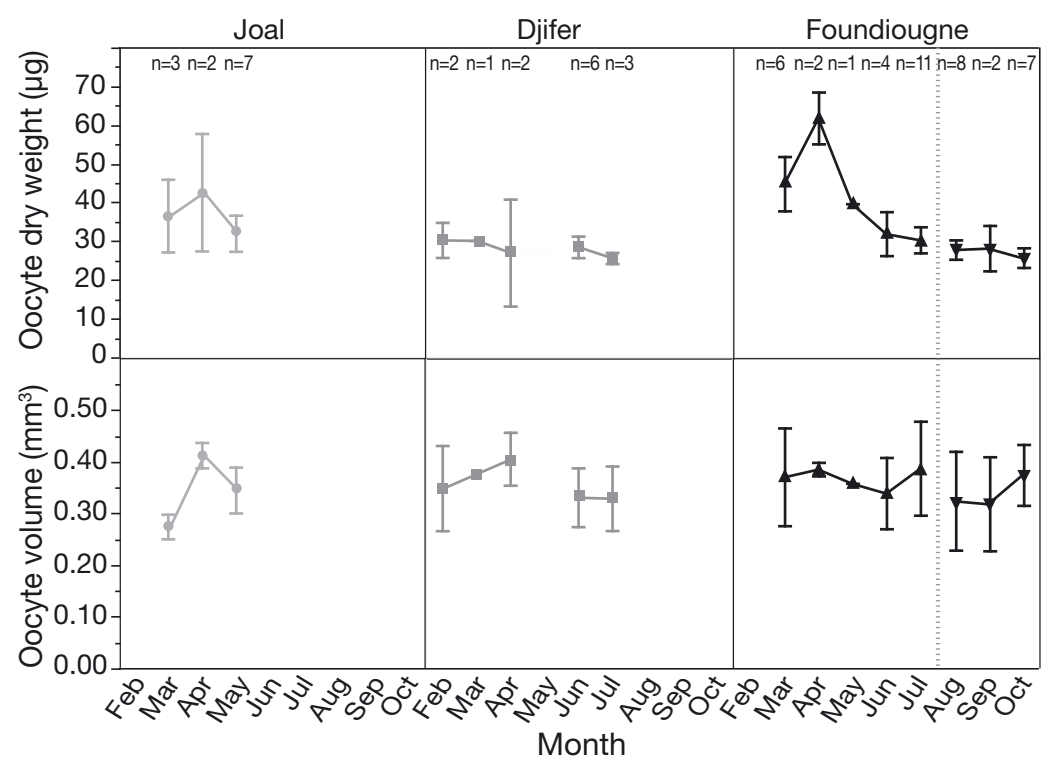

Fig. 3. Monthly differences in dry weights and volumes (mean \pm SD) in Ethmalosa fimbriata oocytes at the 3 sampling sites at the Senegalese coast (Joal) and inside the Saloum estuary (Djifer, Foundiougne) in 2014 and seasons. The proportions of PUFA were higher at Foundiougne (during the dry and wet season) than at Joal and Djifer, albeit not significantly. The SAFA 16:0 (palmitic acid) constituted the largest mean percentage of the oocytes, followed by either 18:0 (stearic acid) or 18:1 (n-9) (oleic acid). The 3 most abundant FA constituted between 66 and $71 \%$ of the total (Table 1). Proportions of 18:0 (ANOVA, $F_{(3,70)}=$ $3.5430, \mathrm{p}<0.05)$ and 18:1 (n-9) (ANOVA, $F_{(3,70)}=$ $5.5882, \mathrm{p}<0.01)$ were significantly lower in oocytes of females sampled at Foundiougne during the wet season when compared to the other sampling sites and seasons. A monthly comparison revealed no significant differences in oocyte 18:0 fractions at all 3 sampling sites. However, 18:1 (n-9) was significantly lower in oocytes sampled at Joal (ANOVA, $F_{(2,12)}=$ $6.6282, \mathrm{p}<0.05)$ in March than in May, whereas in oocytes sampled at Foundiougne, the FA was significantly lower in October than in April (ANOVA, $F_{(7,43)}$ $=3.3316, \mathrm{p}<0.01$; Fig. 4).

The proportions of ARA were significantly lower in oocytes of females sampled at Joal than those sampled at Foundiougne during the wet season (ANOVA, $\left.F_{(3,70)}=9.5558, \mathrm{p}<0.0001\right)$. Further, oocyte ARA proportions at Djifer were significantly lower in February than in July (ANOVA, $F_{(4,13)}=5.9892$, $\mathrm{p}<$ $0.05)$. At this station, however, the proportions of EPA were significantly higher in July than in February (ANOVA, $\left.F_{(4,13)}=4.8521, \mathrm{p}<0.05\right)$. While monthly differences in DHA became apparent, these differences were not significant (Fig. 5). The ratio of $\Sigma$ (n-3) to $\Sigma$ (n-6) FA was higher in oocytes of fish sampled at Djifer and at Foundiougne during the dry season when compared to oocytes sampled at Joal and at Foundiougne during the wet season, albeit not significantly. The FA 16:1 (n-7) constituted rather large averages of 5.7 to $7.0 \%$, and 18:1 (n-7) accounted for 3.4 to $4.2 \%$.

\section{Relationships between female repro- ductive investment, oocyte fatty acid compositions, and physical parameters}

Results of the modelled relationships between oocyte FA compositions, female reproductive investment (ODW, OW, RBF, GSI), and physical parameters are given in Table 2. A positive correlation between $\mathrm{RBF}$ and water temperature as well as salinity became apparent. ODW was neg- 


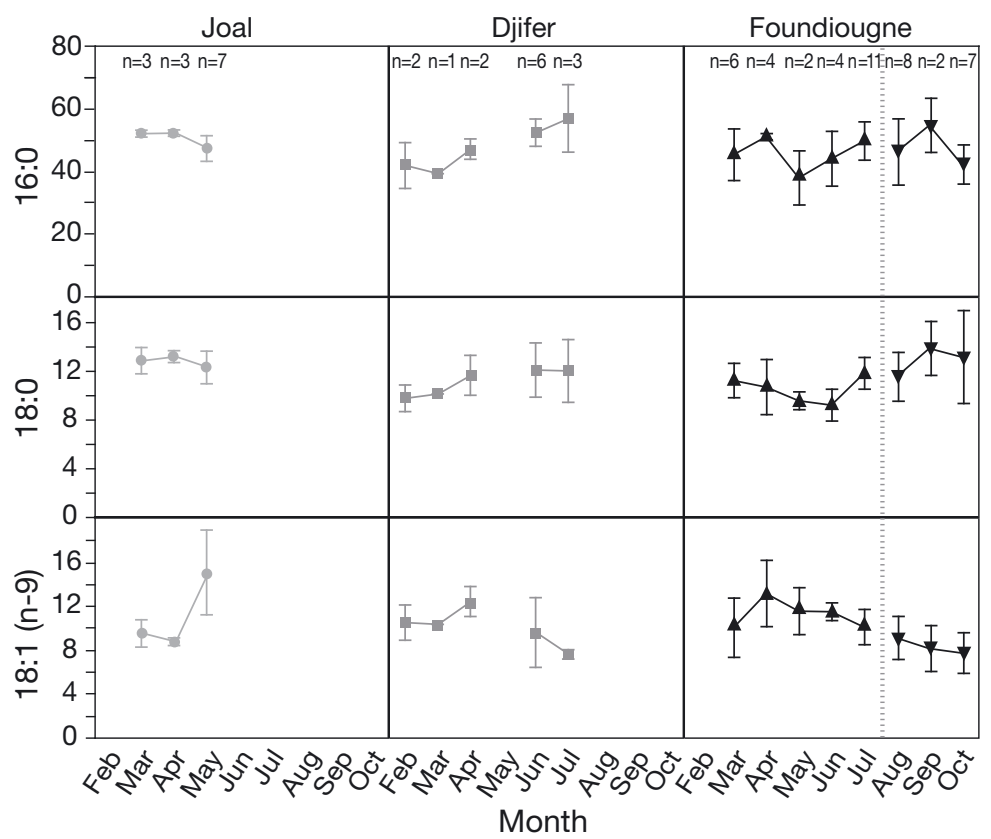

Fig. 4. Monthly differences in the most abundant fatty acids 16:0, 18:0, and 18:1 (n-9) (as \% of total fatty acids) (mean \pm SD) in Ethmalosa fimbriata oocytes at the 3 sampling sites at the Senegalese coast (Joal) and inside the Saloum estuary (Djifer, Foundiougne) in 2014

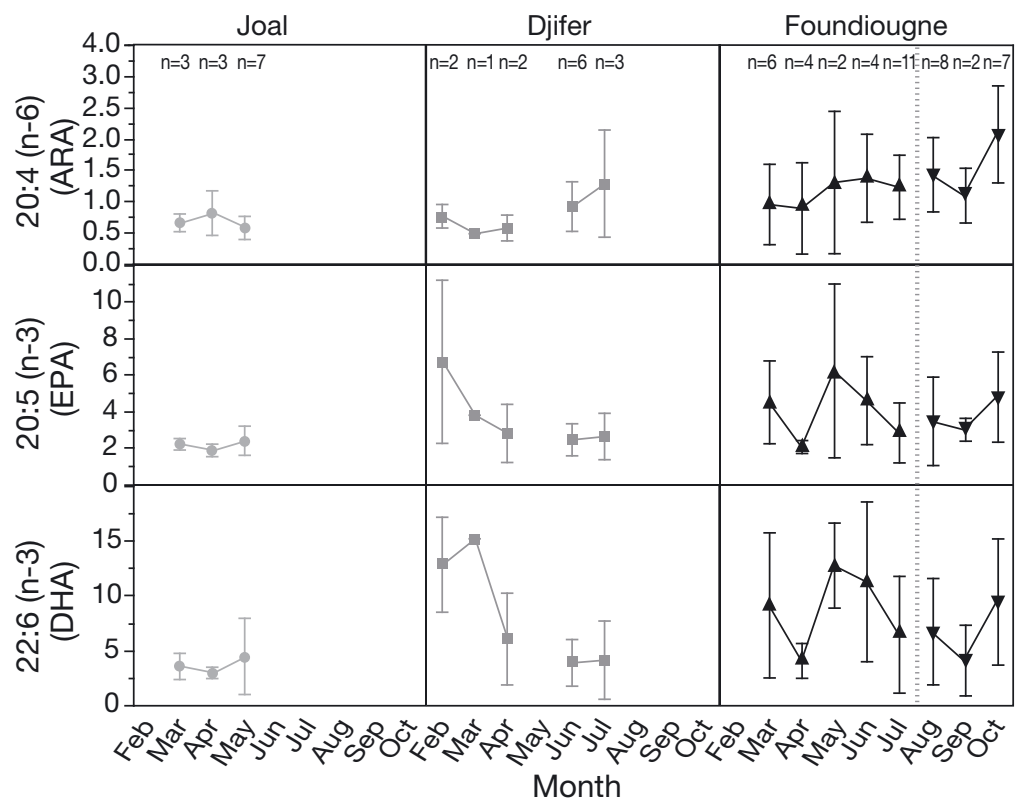

Fig. 5. Monthly differences in the essential fatty acids 20:4 (n-6), 20:5 (n-3), and 22:6 (n-3) (as \% of total fatty acids) (mean \pm SD) in Ethmalosa fimbriata oocytes at the 3 sampling sites at the Senegalese coast (Joal) and inside the Saloum estuary (Djifer, Foundiougne) in 2014. ARA: arachidonic acid; DHA: docosahexaenoic acid; EPA: eicosapentaenoic acid

atively correlated with temperature and positively with salinity. The interaction of temperature and salinity, however, had a negative effect on ODW. Thus, under high salinity and high temperature con- ditions, females were producing higher numbers of oocytes albeit of lower dry weights.

The oocyte proportions of 18:1 (n-9) were positively correlated with OFBW and negatively with OW (Table 2, Fig. 6a). Oocyte ARA fractions were positively correlated with surface water temperature and RBF (Table 2, Fig. 6b). Salinity had a negative quadratic effect on EPA, while female GSI had a positive and linear effect on this EFA (Table 2, Fig. 6c). Additionally, salinity had a negative and quadratic effect on DHA. The apex of the function was determined to occur at a salinity of 45 (Fig. 6d). Females spawning under intermediate salinity and high temperature conditions exhibited high ratios of ovary weight to body weight and high batch fecundities. These spawners were also able to invest higher proportions of examined EFA into their oocytes.

\section{Spatial and seasonal patterns in oocyte fatty acid compositions}

PCA was used to investigate spatially and seasonally resolved differences in the most abundant FAs in the examined oocytes as well as EFA marker compositions. The first principal axis (PC1) explained $59.2 \%$ of the observed variability and mainly separated the sampling location of oocytes by their FA levels in 16:0 and 18:0, as well as ARA, EPA, and DHA. FA levels of oocytes sampled at the Senegalese coast (Joal) were mainly described by negative PC1 loadings and thus by an increase in unsaturated FA. The second axis (PC2) separated oocytes according to the proportions of ARA and 18:1 (n-9) and explained $22.2 \%$ of the observed variance. The distribution of samples in the PCA plot showed strong overlaps between sampling sites/seasons. However, a distinct difference between the FA composition of oocytes sampled at Joal and Foundiougne during the wet season became apparent (Fig. 7).

\section{Examination of trophic footprints}

To evaluate a potential influence of site-specific differences in food items, the feeding history of $E$. fimbriata was investigated by analysing the FA com- 


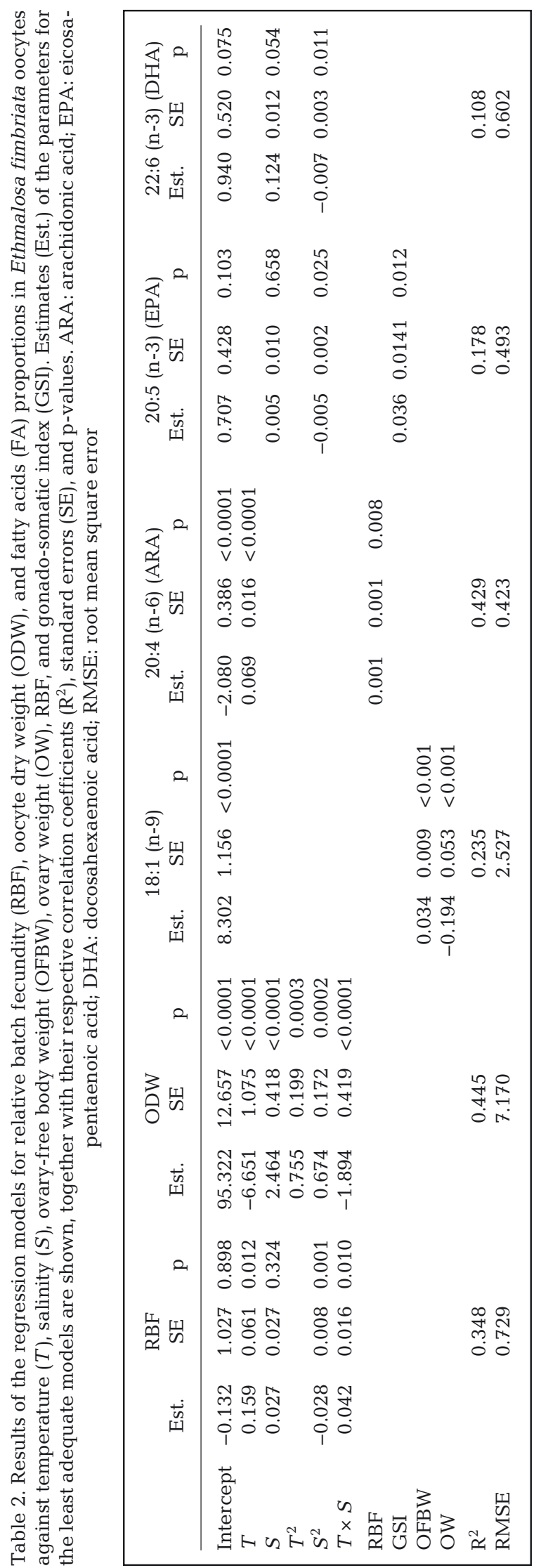

position of phytoplankton, female stomach contents, and oocytes at all 3 sampling stations at the end of the wet season (November 2016). ARA (ANOVA, $F_{(2,8)}=$ 13.2329, $\mathrm{p}<0.01$ ) and EPA (ANOVA, $F_{(2,8)}=17.4766$, $\mathrm{p}<0.01$ ) were significantly lower in the phytoplankton sampled at Foundiougne than at Joal and Djifer (Fig. 8). DHA values were significantly lower in phytoplankton sampled at Foundiougne than at Joal, with intermediate values recorded at Djifer (ANOVA, $F_{(2,8)}=$ 95.7254, $\mathrm{p}<0.0001)$. The FA 16:1 (n-7) contributed an average of $7 \%$ to the phytoplankton total FA at Joal, whereas at Foundiougne this FA showed significantly higher proportions, varying around 12\% (ANOVA, $\left.F_{(2,8)}=6.7892, \mathrm{p}<0.05\right)$. The FA 18:1 (n-7) was, however, significantly higher in the phytoplankton sampled at Joal $(4.7 \%)$ when compared to Djifer and Foundiougne, with mean values of 2.3 and $1.9 \%$, respectively (ANOVA, $F_{(2,8)}=69.0017, \mathrm{p}<0.0001$ ) (data not shown). No significant spatial differences in EFA composition nor in 16:1 (n-7) and 18:1 (n-7) could be determined in the stomach contents and oocyte compositions of females. However, especially at Foundiougne, distinct differences between the EFA proportions of phytoplankton, stomach contents, and oocytes became apparent (Fig. 8).

\section{DISCUSSION}

The reproductive potential of a stock is strongly associated with female reproductive effort and gamete quality (Trippel 1999, Jakobsen et al. 2009). Egg quality, often taken as a measure for hatching success or viability of early larval stages (Morgan 2008), can be related to many factors: the size or weight of the oocyte (Blaxter \& Hempel 1963); the amount of nutrients, lipids, and proteins deposited into the oocyte (Brooks et al. 1997); and also the FA composition of the oocyte (Wiegand 1996). We investigated oocyte quality in terms of FA composition in relation to individual reproductive investment and how it is influenced by ambient temperature and salinity in a hypersaline estuary.

Observed water temperature and salinity variations in 2014 followed a seasonal pattern typical for the Sine Saloum estuary (Simier et al. 2004). Water temperature steadily increased until the end of the wet season in October. The highest salinity values were recorded in July, at the end of the dry season, and the lowest in September/October, at the end of the wet season. Ethmalosa fimbriata produced increasing numbers of oocytes, along a rising temperature and salinity gradient. However, the interaction of temperature and salinity exhibited negative effects on the weight of the 

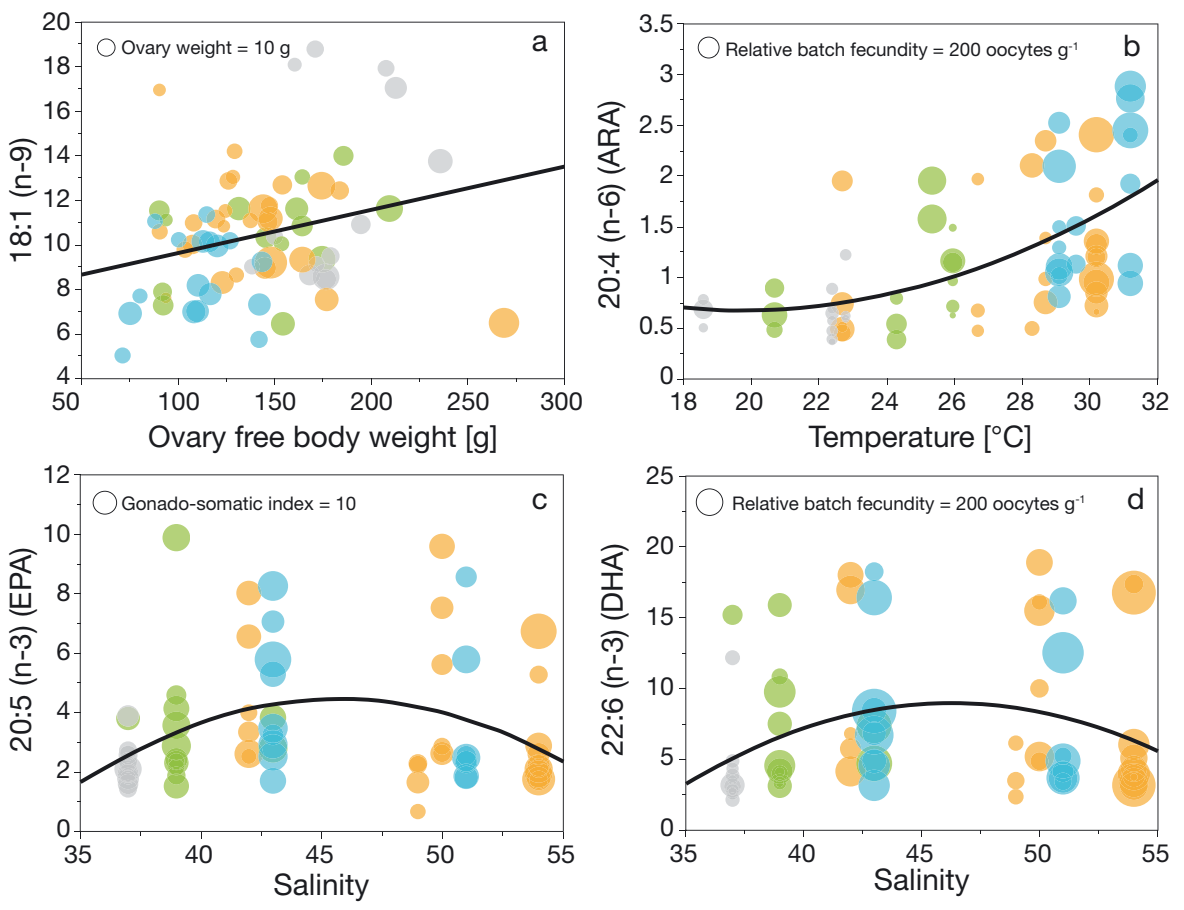

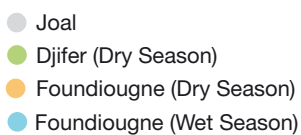

Fig. 6. Relationships of 4 investigated fatty acids (as \% of total fatty acids) with (a) female ovary-free body weight, (b) temperature, and $(\mathrm{c}, \mathrm{d})$ salinity. Respective bubble sizes display the ovary weights, relative batch fecundity, and gonado-somatic index of individual female Ethmalosa fimbriata. Different colours indicate the sampling location and season. ARA: arachidonic acid; DHA: docosahexaenoic acid; EPA: eicosapentaenoic acid hydrated oocytes. Results thus support the assertion that oocyte weight is negatively correlated with batch fecundity in clupeid fishes (Bradford \& Stephenson 1992). OV, however, constituted a conservative spawning trait in E. fimbriata because no differences among sampling sites and seasons were detected. Further, heavier females incorporated more 18:1 (n-9) into their oocytes, even though higher ovary weights led to smaller fractions of this FA in the produced oocytes. Peters et al. (2015) observed a negative correlation of 18:1 (n-9) proportions with larval length in European sprat Sprattus

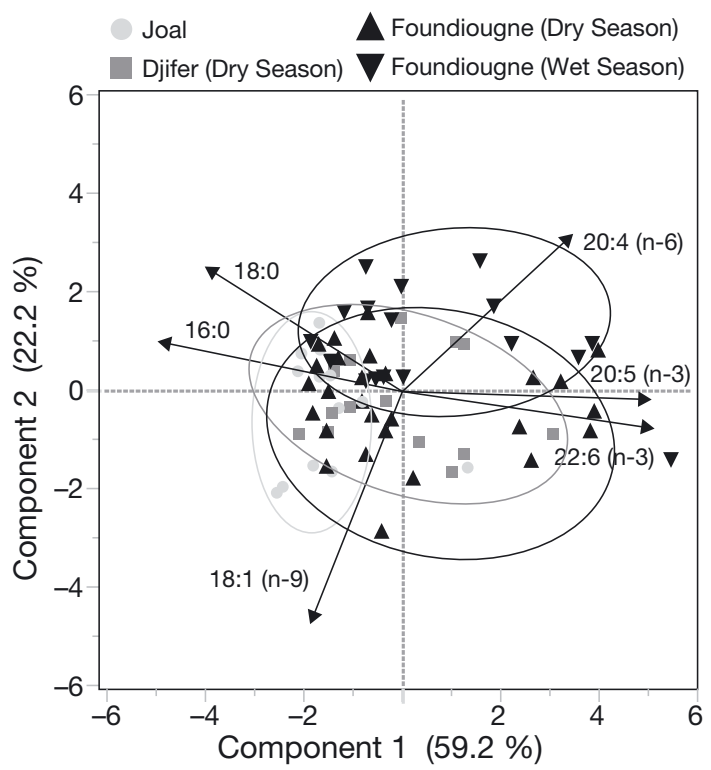

Fig. 7. Principal component analysis on the most abundant fatty acids and essential fatty acids ( $\%$ of total fatty acids) in Ethmalosa fimbriata oocytes sampled at Joal, Djifer (dry season), and Foundiougne (dry and wet season). Ellipses include $75 \%$ of the samples for each sampling site and season

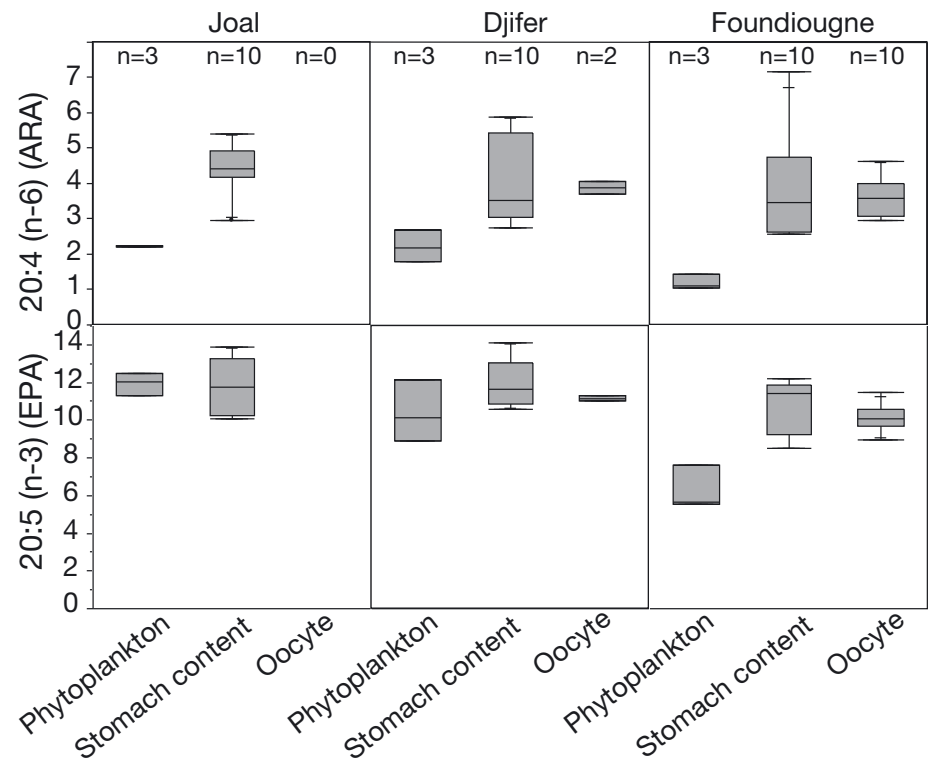

Fig. 8. Proportions of 20:4 (n-6) and 20:5 (n-3) (as \% of total fatty acids) in November 2016 for microphytoplankton in surface waters and for the stomach contents as well as oocytes of female Ethmalosa fimbriata. Box-and-whisker plots display the median (line), interquartile range (box), interdecile range (small whiskers), and the 5th and 95th percentiles (big whiskers). ARA: arachidonic acid; EPA: eicosapentaenoic acid 
sprattus (Linnaeus, 1758) and consequently assigned this particular FA an important role as a storage lipid. Our findings illustrate a trade-off mechanism between ovary weight (number of produced oocytes) and maternal 18:1 (n-9) supply to individual oocytes. Accordingly, Peruvian anchoveta Engraulis ringens (Jenyns, 1842) produced smaller amounts of eggs, albeit of larger sizes and lipid contents, to enhance egg and larvae survival under conditions with low water temperatures and low prey abundances (Castro et al. 2009).

EFA ratios remain more or less constant across the first 3 trophic levels of the food chain (St. John \& Lund 1996). Consequently, EFA profiles and ratios in lipid depots such as oocytes are directly affected by the diet composition of the spawner (Dalsgaard et al. 2003, Castro et al. 2010, Patterson \& Green 2015). Monthly variability in oocyte FA composition and strong correlations of FA biomarkers like ARA, EPA, and DHA with water temperature and salinity suggest immediate dietary effects on oocyte quality (Leray et al. 1984, March 1993, Patterson \& Green 2015). However, the observed high variances in oocyte FA composition in E. fimbriata might be due to migratory behavior. Diet to egg transfer of ARA takes 2 to $16 \mathrm{~d}$ in batch-spawning fishes (Fuiman \& Faulk 2013). Given the rather small geographical ranges in the Sine Saloum (15 to $45 \mathrm{~km}$ ), E. fimbriata individuals may easily migrate during this timeframe into the estuary to spawn after feeding in the ocean. In general, spawning migration combined with shortinterval batch spawning is regarded as an adaptation to take direct advantage of nutrients critical for offspring survival which are available at the spawning site (Fuiman \& Faulk 2013). Conversely, feeding on phytoplankton with beneficial attributes (i.e. FA compositions) for the survival of early life stages at a certain location/time might also be a viable strategy in heterogeneous environments (Crawford et al. 1986). Accordingly, Spanish sardine Sardinella aurita (Valenciennes, 1847) stored energy in the form of lipids during the highly productive upwelling season, which was later (after $5 \mathrm{mo}$ ) released via metabolism for gamete production (Fréon et al. 1997).

Further evidence for migratory movements between marine feeding and estuarine spawning grounds is provided by the results of the sampling campaign conducted in November 2016 (end of rainy season). At Joal and Djifer, the EPA proportions in female stomach contents and oocytes reflected the EPA values of the sampled phytoplankton. At Foundiougne, the deviation in EPA proportions in phytoplankton and stomach contents/oocytes can only be explained by feeding migration. Still, the fractions of ARA in the phytoplankton did not mirror the stomach contents of females at all sampling sites. We explain this result by the spatial-temporal variability (patchiness) in estuarine and coastal phytoplankton communities. These deviations may also hint towards a certain selectivity in the species' feeding behavior. Phytoplankton at Joal was sampled close to the beach, explaining the higher observed fractions in the biomarker for organic detritus 18:1 (n-7) and lower fractions in the diatom biomarker 16:1 (n-7) when compared to estuarine samples.

E. fimbriata mainly feeds on diatoms and dinoflagellates (Bainbridge 1961, Blay \& Eyeson 1982a), but literature on phytoplankton community composition in tropical hypersaline environments is scarce. The most dominant taxa under hypersaline conditions in a South African estuary were cyanobacteria, although a resilience to high salinities was also detected in diatoms (Nche-Fambo et al. 2015). The trophic marker for a diatom-based diet 16:1 (n-7) indeed constituted rather large averages in all examined oocytes (Dalsgaard et al. 2003). Biomarkers for cyanobacteria 18:3 (n-6) and heterotrophic organisms 20:1 (n-9) and 22:1 (n-11), on the other hand, were absent in our samples (Dalsgaard et al. 2003, Yang et al. 2016). DHA to EPA ratios in oocytes greatly exceeded 1 at all sampling sites, which indicates a dinoflagellate-based ecosystem (Dalsgaard et al. 2003). However, the small ratios $(<0.5 \%)$ of dinoflagellate-specific biomarkers such as 18:4 (n-3) and $18: 3(n-3)$ in the sampled oocytes make a dinoflagellate-based diet highly unlikely (Kopprio et al. 2015, Peters et al. 2015). The FA 18:1 (n-7) and 18:1 (n-9) were found to be quite relevant in the investigated oocytes, suggesting a contribution from detrital material to the spawners' diet (Fahl \& Kattner 1993). Overall, these findings agree with our microscopic observations and classify the food of E. fimbriata as mainly consisting of diatoms and degenerated organic matter.

At lower temperatures, phytoplankton increase cell membrane PUFA levels to maintain a certain level of fluidity. Inversely, higher SAFA levels are required at higher temperatures to maintain membrane integrity (Guschina \& Harwood 2006, Hixson \& Arts 2016). This process is commonly referred to as homeoviscous adaptation (Sinensky 1974). In agreement with these findings, E. ringens eggs sampled in cold waters off the coast of Chile exhibited high PUFA levels, whereas eggs sampled in warmer waters were characterized by higher SAFA and MUFA values (Castro et al. 2010). Consumption of phytoplankton adapted to high water temperatures 
thus explains the generally high ratios of SAFA in our material from warm tropical waters when compared to FA profiles in eggs and larvae of temperate clupeid species (Tocher et al. 1985, Peters et al. 2015). Additionally, increased temperatures were generally negatively correlated with (n-3) PUFA but positively correlated with (n-6) PUFA in phytoplankton (Hixson \& Arts 2016). Females spawning in middle reaches of the Saloum River were indeed able to equip their oocytes with significantly higher ARA fractions, and this particular EFA was positively correlated with water temperature. Apart from ARA, however, females spawning inside the estuary generally equipped their oocytes with higher EFA proportions as illustrated by PCA and their positive relationships with spawner reproductive investment and salinity.

Amino acids derived from yolk hydrolysis and ions, such as $\mathrm{K}^{+}, \mathrm{Cl}^{-}, \mathrm{P}_{\mathrm{i}}$, and $\mathrm{NH}_{4}{ }^{+}$, are the main components of fish oocyte osmolality (Finn et al. 2002, Lubzens et al. 2010). In general, osmoregulation in the embryo begins with the development of extrabranchial ionocytes, which are located in the entire integument, especially on the yolk sac (Alderdice 1988, Kaneko et al. 2002, Seo et al. 2015). Ionocytes are rich in $\mathrm{Na}^{+} / \mathrm{K}^{+}$ATPase (McCormick 1993, Armesto et al. 2014) and have been shown to be the site of ion excretion in fish acclimated to hypersaline environments (Foskett \& Scheffey 1982). Prostaglandins are lipid compounds that regulate electrolyte balance at several sites in fish cells, including the $\mathrm{Na}^{+} / \mathrm{Cl}^{-}$co-transporter and the $\mathrm{Na}^{+} / \mathrm{K}^{+}$-ATPase (Van Praag et al. 1987). Conversion of ARA to prostaglandin in gills and other tissues has been reported in several teleost fishes (Ogata et al. 1978, Henderson et al. 1985, Beckman \& Mustafa 1992). Enhanced dietary intake of ARA thus increased prostaglandin production (Bransden et al. 2004) and thereby the resistance to hyperosmotic stress in a variety of fish larvae (Willey et al. 2001, Koven et al. 2003). Further, the ratios of (n-3) to (n-6) PUFA in oocytes sampled from Djifer and Foundiougne during the dry season were numerically higher than at Joal and at Foundiougne during the wet season, albeit not significantly. It has been shown before that elevated levels in the ratio of (n-3) to (n-6) PUFA in gill lipids of European eel Anguilla anguilla enhanced their ability to maintain osmotic equilibrium in waters of different salinities at different temperatures (Thomson et al. 1977, March 1993). E. fimbriata larvae from Sine Saloum hatching from oocytes with higher ratios of ARA and higher ratios of (n-3) to (n-6) PUFA are therefore more likely to develop normally and survive in hypersaline environments, as they show elevated osmoregulatory capabilities.
The results obtained in the present study highlight the importance of incorporating information on oocyte quality in terms of FA composition in the assessment of stock reproductive potential. Under the hypersaline conditions inside the Sine Saloum estuary (temperature $>27^{\circ} \mathrm{C}$, salinity $\sim 46$ ), individual E. fimbriata spawned not only more eggs (per $g$ female) but also eggs of higher quality. Female reproductive potential is therefore determined to be highest when spawning occurs inside the estuary at the end of the wet season (September/October), when temperatures are high and salinities are less stressful due to freshwater input. These findings, however, partly contradict the current paradigm that oocyte quality is negatively correlated with batch fecundity in teleost fishes.

\section{Conclusions}

Past studies have shown that spawning stock biomass exhibits a limited capacity to predict recruitment. More promising might be the determination of physiological strength in reproduction products to estimate the survival potential of a stock. Maternal and environmental effects on recruitment play a significant role and have to be understood for a more effective stock management. Our results highlight the importance of considering differences in gamete viability with respect to their EFA composition. Observed differences in oocyte FA profiles are linked to the individual's reproductive investment and to different environmental conditions. This variability likely impacts the survival probability of early life stages and thus the reproductive potential of species such as Ethmalosa fimbriata, which serves as an example for clupeid fishes reproducing under extreme conditions.

Acknowledgements. This study was conducted within the framework of the trilateral project 'Ecosystem approach to the management of fisheries and the marine environment in West African waters' (AWA; funding no. 01DG12073B). The authors thank Hans Sloterdijk, Ousseynou Samba, and Luc Bonaventure Badji for their help during the field sampling. We are grateful to Constanze von Waldthausen, Stefanie Bröhl, and Raika Himmelsbach, who were of great help during preparations of the field sampling campaigns and the FA analysis in the laboratory. We thank Amanda Ford, Carola Wagner, and Germán Kopprio for reviewing the manuscript's draft. We also thank Patrice Brehmer, Timothée Brochier, and everyone involved in the AWA project for always providing a helping hand. We further thank the 3 anonymous reviewers for their valuable comments on a former version of this article. 


\section{LITERATURE CITED}

Ackman RG, Jangaard PM (1964) Origin of marine fatty acids. I. Analyses of the fatty acids produced by the diatom Skeletonema costatum. J Fish Res Board Can 21: $747-756$

Albaret JJ, Gerlotto F (1976) Biologie de l'Ethmalose (Ethmalosa fimbriata Bowdich) en cote D'Ivoire. I.-Description de la reproduction et des premiers stades larvaires. Doc Sci Cent Rech Oceanogr Abidjan 7:113-133

Alderdice DF (1988) Osmotic and ionic regulation in teleost eggs and larvae. Fish Physiol 11:163-251

Alderdice DF, Rosenthal H, Velsen FPJ (1979) Influence of salinity and cadmium on the volume of Pacific herring eggs. Helgol Wiss Meeresunters 32:163-178

Alheit J (1988) Reproductive biology of sprat (Sprattus sprattus): factors determining annual egg production. ICES J Mar Sci 44:162-168

Armesto P, Campinho MA, Rodríguez-Rúa A, Cousin X, Power DM, Manchado M, Infante C (2014) Molecular characterization and transcriptional regulation of the $\mathrm{Na}+/ \mathrm{K}+$ ATPase $\alpha$ subunit isoforms during development and salinity challenge in a teleost fish, the Senegalese sole (Solea senegalensis). Comp Biochem Physiol B Biochem Mol Biol 175:23-38

Asil SM, Kenari AA, Miyanji GR, Van Der Kraak G (2017) The influence of dietary arachidonic acid on growth, reproductive performance, and fatty acid composition of ovary, egg and larvae in an anabantid model fish, blue gourami (Trichopodus trichopterus; Pallas, 1770). Aquaculture 476:8-18

Bainbridge V (1961) The early life history of the bonga, Ethmalosa dorsalis (Cuvier and Valenciennes). J Cons Int Explor Mer 3:347-353

Bainbridge V (1963) The food, feeding habits and distribution of the bonga Ethmalosa dorsalis (Cuvier \& Valenciennes). J Cons Int Explor Mer 28:270-283

Beckman B, Mustafa T (1992) Arachidonic acid metabolism in gill homogenate and isolated gill cells from rainbow trout, Oncorhynchus mykiss: the effect of osmolality, electrolytes and prolactin. Fish Physiol Biochem 10: 213-222

Bell JG, Tocher DR, Sargent JR (1994) Effect of supplementation with 20:3(n-6), 20:4(n-6) and 20:5(n-3) on the production of prostaglandins $\mathrm{E}$ and $\mathrm{F}$ of the 1-, 2- and 3series in turbot (Scophthalmus maximus) brain astroglial cells in primary culture. Biochim Biophys Acta 1211: 335-342

Blaxter JHS, Hempel G (1963) The influence of egg size on herring larvae (Clupea harengus L.). ICES J Mar Sci 28: 211-240

Blay J Jr, Eyeson KN (1982a) Feeding activity and food habits of the shad, Ethmalosa fimbriata (Bowdich), in the coastal waters of Cape Coast, Ghana. J Fish Biol 21: 403-410

Blay J Jr, Eyeson KN (1982b) Observations on the reproductive biology of the shad, Ethmalosa fimbriata (Bowdich), in the coastal waters of Cape Coast, Ghana. J Fish Biol 21:485-496

Bradford RG, Stephenson RL (1992) Egg weight, fecundity, and gonad weight variability among Northwest Atlantic herring (Clupea harengus) populations. Can J Fish Aquat Sci 49:2045-2054

Bransden MP, Cobcroft JM, Battaglene SC, Dunstan GA, Nichols PD, Bell JG (2004) Dietary arachidonic acid alters tissue fatty acid profile, whole body eicosanoid production and resistance to hypersaline challenge in larvae of the temperate marine fish, striped trumpeter (Latris lineata). Fish Physiol Biochem 30:241-256

* Brooks S, Tyler CR, Sumpter JP (1997) Egg quality in fish: What makes a good egg? Rev Fish Biol Fish 7:387-416

*Bown JA, Bucknall RM (1986) Antidiuretic and cardiovascular actions of PGE2 in the rainbow trout Salmo gairdneri. Gen Comp Endocrinol 61:330-337

*Bown MB, Forsythe AB (1974) The small sample behavior of some statistics which test the equality of several means. Technometrics 16:129-132

* Castro LR, Claramunt G, Krautz MC, Llanos-Rivera A, Moreno P (2009) Egg trait variation in anchoveta Engraulis ringens: a maternal response to changing environmental conditions in contrasting spawning habitats. Mar Ecol Prog Ser 381:237-248

Castro LR, Claramunt G, González HE, Krautz MC and others (2010) Fatty acids in eggs of anchoveta Engraulis ringens during two contrasting winter spawning seasons. Mar Ecol Prog Ser 420:193-205

Charles-Dominique E (1982) Exposé synoptique des données biologiques sur l'ethmalose (Ethmalosa fimbriata $\mathrm{S}$. Bowdich, 1825). Rev Hydrobiol Trop 14:373-397

Charles-Dominique E, Albaret JJ (2003) African shads, with emphasis on the West African shad Ethmalosa fimbriata. In: Limburg KE, Waldman JR (eds) Biodiversity, status, and conservation of the world's shads. Am Fish Soc Symp $35: 27-48$

* Crawford RH, Cusack RR, Parlee TR (1986) Lipid content and energy expenditure in the spawning migration of alewife (Alosa pseudoharengus) and blueback herring (Alosa aestivalis). Can J Zool 64:1902-1907

* Dalsgaard J, St. John MA, Kattner G, Müller-Navarra D, Hagen W (2003) Fatty acid trophic markers in the pelagic marine environment. Adv Mar Biol 46:225-340

*Döring J, Tiedemann M, Stäbler M, Sloterdijk H, Ekau W (2017) Ethmalosa fimbriata (Bowdich 1825), a clupeid fish that exhibits elevated batch fecundity in hypersaline waters. Fishes 2:13

Facade SO, Olaniyan CIO (1972) The biology of the West African shad Ethmalosa fimbriata (Bowdich) in the Lagos Lagoon, Nigeria. J Fish Biol 4:519-533

Fahl K, Kattner G (1993) Lipid content and fatty acid composition of algal communities in sea-ice and water from the Weddell Sea (Antarctica). Polar Biol 13:405-409

*Finn RN, Østby GC, Norberg B, Fyhn HJ (2002) In vivo oocyte hydration in Atlantic halibut (Hippoglossus hippoglossus); proteolytic liberation of free amino acids, and ion transport, are driving forces for osmotic water influx. J Exp Biol 205:211-224

Foskett JK, Scheffey C (1982) The chloride cell: definitive identification as the salt-secretory cell in teleosts. Science 215:164-166

Fréon P, El Khattabi M, Mendoza J, Guzmán R (1997) Unexpected reproductive strategy of Sardinella aurita off the coast of Venezuela. Mar Freshw Res 128:363-372

* Fuiman LA, Faulk CK (2013) Batch spawning facilitates transfer of an essential nutrient from diet to eggs in a marine fish. Biol Lett 9:20130593

F Fuiman LA, Connelly TL, Lowerre-Barbieri SK, McClelland JW (2015) Egg boons: central components of marine fatty acid food webs. Ecology 96:362-372

*Garrido S, Rosa R, Ben-Hamadou R, Cunha ME, Chícharo MA, van der Lingen CD (2007) Effect of maternal fat 
reserves on the fatty acid composition of sardine (Sardina pilchardus) oocytes. Comp Biochem Physiol B Biochem Mol Biol 148:398-409

*Guschina IA, Harwood JL (2006) Mechanisms of temperature adaptation in poikilotherms. FEBS Lett 580: 5477-5483

Hempel G (1979) Early life history of marine fish: the egg stage. University of Washington Press, Seattle, WA

* Henderson RJ, Bell MV, Sargent JR (1985) The conversion of polyunsaturated fatty acids to prostaglandins by tissue homogenates of the turbot, Scophthalmus maximus (L.). J Exp Mar Biol Ecol 85:93-99

* Hixson SM, Arts MT (2016) Climate warming is predicted to reduce omega-3, long-chain, polyunsaturated fatty acid production in phytoplankton. Glob Change Biol 22: 2744-2755

Holliday FGT (1969) The effects of salinity on the eggs and larvae of teleosts. Fish Physiol 1:293-311

Horseman ND, Meier AH (1978) Prostaglandin and the osmoregulatory role of prolactin in a teleost. Life Sci 22: 1485-1490

Hunter JR, Lo NCH, Leong RJH (1985) Batch fecundity in multiple spawning fishes. NOAA Tech Rep NMFS:67-77

Jakobsen T, Fogarty MJ, Megrey BA, Moksness E (eds) (2009) Fish reproductive biology: implications for assessment and management, 1st edn. Wiley-Blackwell, Oxford

Jatteau P, Drouineau H, Charles K, Carry L, Lange F, Lambert P (2017) Thermal tolerance of allis shad (Alosa alosa) embryos and larvae: modeling and potential applications. Aquat Living Resour 30:2

Kaneko T, Shiraishi K, Katoh F, Hasegawa S, Hiroi J (2002) Chloride cells during early life stages of fish and their functional differentiation. Fish Sci 68:1-9

Kopprio GA, Lara RJ, Martínez A, Fricke A, Graeve M, Kattner G (2015) Stable isotope and fatty acid markers in plankton assemblages of a saline lake: seasonal trends and future scenario. J Plankton Res 37:584-595

Koven W, Van Anholt R, Lutzky S, Ben Atia I, Nixon O, Ron B, Tandler A (2003) The effect of dietary arachidonic acid on growth, survival, and cortisol levels in different-age gilthead seabream larvae (Sparus auratus) exposed to handling or daily salinity change. Aquaculture 228: 307-320

Lane RL, Kohler CC (2006) Effects of dietary lipid and fatty acids on white bass reproductive performance, egg hatchability, and overall quality of progeny. N Am J Aquaculture 68:141-150

Lazzaro X (1987) A review of planktivorous fishes: their evolution, feeding behaviours, selectivities, and impacts. Hydrobiologia 146:97-167

Lee RF, Nevenzel JC, Paffenhöfer GA (1971) Importance of wax esters and other lipids in the marine food chain: phytoplankton and copepods. Mar Biol 9:99-108

* Leray C, Chapelle S, Duportail G, Florentz A (1984) Changes in fluidity and 22:6(n-3) content in phospholipids of trout intestinal brush-border membrane as related to environmental salinity. Biochim Biophys Acta - Biomembr 778:233-238

* Leray C, Nonnotte G, Roubaud P, Léger C (1985) Incidence of (n-3) essential fatty acid deficiency on trout reproductive processes. Reprod Nutr Dev 25:567-581

Linko RR, Kaitaranta JK, Vuorela R (1985) Comparison of the fatty acids in Baltic herring and available plankton feed. Comp Biochem Physiol B 82:699-705
* Lubzens E, Young G, Bobe J, Cerdà J (2010) Oogenesis in teleosts: how fish eggs are formed. Gen Comp Endocrinol 165:367-389

March BE (1993) Essential fatty acids in fish physiology. Can J Physiol Pharmacol 71:684-689

Martin TJ (1988) Interaction of salinity and temperature as a mechanism for spatial separation of three co-existing species of Ambassidae (Cuvier) (Teleostei) in estuaries on the south-east coast of Africa. J Fish Biol 33:9-15

McCormick SD (1993) Methods for nonlethal gill biopsy and measurement of $\mathrm{Na}^{+}, \mathrm{K}^{+}$-ATPase activity. Can J Fish Aquat Sci 50:656-658

Morgan MJ (2008) Integrating reproductive biology into scientific advice for fisheries management. J Northwest Atl Fish Sci 41:37-51

* Mustafa T, Srivastava K (1989) Prostaglandins (eicosanoids) and their role in ectothermic organisms. Adv Comp Environ Physiol 5:157-207

Nche-Fambo FA, Scharler UM, Tirok K (2015) Resilience of estuarine phytoplankton and their temporal variability along salinity gradients during drought and hypersalinity. Estuar Coast Shelf Sci 158:40-52

* Ogata H, Nomura T, Hata M (1978) Prostaglandin biosynthesis in the tissue homogenates of marine animals. Bull Jpn Soc Sci Fish 44:1367-1370

* Pagès J, Citeau J (1990) Rainfall and salinity of a Sahelian estuary between 1927 and 1987. J Hydrol (Amst) 113: 325-341

* Panfili J, Durand JD, Mbow A, Guinand B and others (2004) Influence of salinity on life history traits of the bonga shad Ethmalosa fimbriata (Pisces, Clupeidae): comparison between the Gambia and Saloum estuaries. Mar Ecol Prog Ser 270:241-257

* Panfili J, Thior D, Ecoutin JM, Ndiaye P, Albaret JJ (2006) Influence of salinity on the size at maturity for fish species reproducing in contrasting West African estuaries. J Fish Biol 69:95-113

*Patterson JT, Green CC (2014) Diet-induced fatty acid variation in critical tissues of a spawning estuarine fish and consequences for larval fitness. Physiol Biochem Zool 87 : $612-622$

* Patterson JT, Green CC (2015) Physiological management of dietary deficiency in n-3 fatty acids by spawning Gulf killifish (Fundulus grandis). Fish Physiol Biochem 41: 971-979

* Peters J, Diekmann R, Clemmesen C, Hagen W (2015) Lipids as a proxy for larval starvation and feeding condition in small pelagic fish: a field approach on matchmismatch effects on Baltic sprat. Mar Ecol Prog Ser 531: $277-292$

Pickova J, Dutta PC (1997) Early embryonic cleavage pattern, hatching success, and egg-lipid fatty acid composition: comparison between two cod (Gadus morhua) stocks. Can J Fish Aquat Sci 54:2410-2416

* Ridd PV, Stieglitz T (2002) Dry season salinity changes in arid estuaries fringed by mangroves and saltflats. Estuar Coast Shelf Sci 54:1039-1049

* Sargent JR, Bell JG, Bell MV, Henderson RJ, Tocher DR (1995) Requirement criteria for essential fatty acids. J Appl Ichthyol 11:183-198

Scheffers WJ, Conand F, Reizer C (1972) Etude de Ethmalosa fimbriata (Bowdich) dans la région Sénégamibienne. 1ère note: reproduction et lieux de ponte dans le fleuve Sénégal et la région de Saint-Louis. Doc Sci Cent Rech Oceanogr Dakar-Thiaroye 44 
Schmider E, Ziegler M, Danay E, Beyer L, Bühner M (2010) Is it really robust? Reinvestigating the robustness of ANOVA against violations of the normal distribution assumption. Methodol Eur J Res Methods Behav Soc Sci 6:147-151

Seo MY, Kuroki M, Okamura A, Tsukamoto K, Watanabe S, Kaneko T (2015) Occurrence of larval and adult types of ion-secreting ionocytes in Japanese eel Anguilla japonica. Ichthyol Res 62:487-494

Shirai N, Terayama M, Takeda H (2002) Effect of season on the fatty acid composition and free amino acid content of the sardine Sardinops melanostictus. Comp Biochem Physiol B Biochem Mol Biol 131:387-393

Simier M, Blanc L, Aliaume C, Diouf PS, Albaret JJ (2004) Spatial and temporal structure of fish assemblages in an 'inverse estuary', the Sine Saloum system (Senegal). Estuar Coast Shelf Sci 59:69-86

Sinensky M (1974) Homeoviscous adaptation - a homeostatic process that regulates the viscosity of membrane lipids in Escherichia coli. Proc Natl Acad Sci USA 71: 522-525

Sloterdijk H, Brehmer P, Müller H, Döring J, Ekau W (2017) Composition and structure of the larval fish community related to environmental parameters in a tropical estuary impacted by climate change. Estuar Coast Shelf Sci 197: $10-26$

St. John MA, Lund T (1996) Lipid biomarkers: linking the utilization of frontal plankton biomass to enhanced condition of juvenile North Sea cod. Mar Ecol Prog Ser 131: 75-85

Thomson AJ, Sargent JR, Owen JM (1977) Influence of acclimatization temperature and salinity on $\left(\mathrm{Na}^{+}+\mathrm{K}^{+}\right)-$ dependent adenosine triphosphatase and fatty acid composition in the gills of the eel, (Anguilla Anguilla). Comp Biochem Physiol B 56:223-228

Tiedemann M, Brehmer P (2017) Larval fish assemblages across an upwelling front: indication for active and passive retention. Estuar Coast Shelf Sci 187:118-133

Tocher DR (2003) Metabolism and functions of lipids and

Editorial responsibility: Stylianos Somarakis,

Heraklion, Greece fatty acids in teleost fish. Rev Fish Sci 11:107-184

* Tocher DR (2010) Fatty acid requirements in ontogeny of marine and freshwater fish. Aquacult Res 41:717-732

* Tocher DR, Sargent JR (1984) Analyses of lipids and fatty acids in ripe roes of some northwest European marine fish. Lipids 19:492-499

* Tocher DR, Fraser AJ, Sargent JR, Gamble JC (1985) Lipid class composition during embryonic and early larval development in Atlantic herring (Clupea harengus, L.). Lipids 20:84-89

Trippel EA (1999) Estimation of stock reproductive potential: history and challenges for Canadian Atlantic gadoid stock assessments. J Northwest Atl Fish Sci 25:61-81

Van Praag D, Farber SJ, Minkin E, Primor N (1987) Production of eicosanoids by the killifish gills and opercular epithelia and their effect on active transport of ions. Gen Comp Endocrinol 67:50-57

*Wedderburn SD, Bailey CP, Delean S, Paton DC (2016) Population and osmoregulatory responses of a euryhaline fish to extreme salinity fluctuations in coastal lagoons of the Coorong, Australia. Estuar Coast Shelf Sci 168:50-57

Wiegand MD (1996) Composition, accumulation and utilization of yolk lipids in teleost fish. Rev Fish Biol Fish 6: 259-286

Willey S, Bengston DA, Harel M (2003) Arachidonic acid requirements in larval summer flounder Paralichthys dentalus. Aquac Int 11:131-149

Wolanski E (1986) An evaporation-driven salinity maximum zone in Australian tropical estuaries. Estuar Coast Shelf Sci 22:415-424

* Yang D, Nam S, Hwang SJ, An KG, Park YS, Shin KH, Park S (2016) Fatty acid biomarkers to verify cyanobacteria feeding abilities of herbivorous consumers. J Freshw Ecol 31:77-91

Zydlewski J, McCormick SD, Kunkel JG (2003) Late migration and seawater entry is physiologically disadvantageous for American shad juveniles. J Fish Biol 63: 1521-1537

Submitted: May 5, 2017; Accepted: October 11, 2017

Proofs received from author(s): November 24, 2017 